American Journal of Applied Sciences 9 (9): 1422-1434, 2012

ISSN 1546-9239

(C) 2012 Science Publication

\title{
An Analysis of Operationalization and Acceptability of Business to Business Transaction: A mixed Method Approach
}

\author{
${ }^{1}$ Yusuf Muhammad-Bashir Owolabi, ${ }^{2}$ Ahamed Kameel Mydin Meera, \\ ${ }^{1}$ Gairuzazmi Mat Ghani, ${ }^{1}$ Turkhan Ali Abd Manap and ${ }^{3}$ Moussa Larbani \\ ${ }^{1}$ Department of Economics, \\ ${ }^{2}$ Department of Finance, \\ ${ }^{3}$ Department of Business, \\ Kulliyyah of Economics and Management Sciences, \\ International Islamic University, Malaysia
}

\begin{abstract}
Business to business barter exchange is a form of transaction that is gaining popularity during the economic downtown despite the fact that money exchange supersede the traditional barter exchange due to a number of inherent problems it has. This study explores the operation and user's acceptance of business to business barter exchange in Malaysia that has made barter exchange feasible in the present day sophisticated financial system. Mixed method data analysis was employed to analyze the qualitative and quantitative data collected for the study. The qualitative data was obtained through in-depth interview, observation and document analysis of BBX Malaysia. The quantitative data was obtained from the survey of the BBX members and analysed using PLS technique. The qualitative part explored the operation of BBX from organization through accountability to challenges. The quantitative aspect examined a number of hypotheses to determine the user's future behavioral intention, premised on a number of previous models. The data was found to fit the model well with all the hypothesized links exhibiting the correct signs and four out of six part coefficients statistically significant. More effort should be made to maximize the factors that determine user's acceptace of barter exchange in order to achieve its potential.
\end{abstract}

Key words: Barter exchange, mixed methods, BBX, Partial least square

\section{INTRODUCTION}

The August 2007, Global Financial Crisis is yet another blow on the world monetary system. Upon the sophistication of and advancement in the world financial infrastructure, the whole world was so enmeshed in it that nearly every nation of the world, big or small, has been affected. What started in US as a result deceit inform of securitized subprime loan- financial producthas led the world leaders jostling for way out from the financial imbroglio. A lot of houses have been for closed (US), unemployment rate has been a record high (many countries), the worst after the great depression, many big companies have gone bankrupt (GM, in US) and nations have defaulted in their loan commitment (Dubai, Greece, Ireland,) and more and more show signs of distress (Portugal, Italy, Germany, Spain,) with no sign of recovery in sight. Various governments have responded in various ways, US, UK, Malaysia-bail out/stimulus package, Dubai, Ireland, Greece-debt schedule/austerity measures. Prominent leaders of the world have also called for total over hauling of world monetary system from the scratch as was done at Breton Wood (French President Nicholas Sarkozy, on 26 September, 2008 has called for rethink of financial system from scratch, as done in Breton Wood (George Parker, Tony Barber and Daniel Dombey, October 9, 2008). British Prime Minister Gordon Brown on October 13, 2008 said world leaders need to meet to take new economic system (Agence France-Presse (AFP), October 13, 2008). Russian Prime Minister Vladimir Putin on February 9, 2009 said the present world monetary system has allowed the wealth of the world to concentrate in a country and as such there is need to be a relook at it (Democratic Underground.Com. Jun 16, 2009). At community level, people have started resulting to self help and looking for solution to the credit crunch (Arche in Indonesia and Kelantan state in Malaysia people have started minting gold as a means of wealth preservation and possible alternative currency).

Each time there is financial disorder, nation governments, communities and local organizations have always come up with solutions that suit the individual capability. While governments have always gone for

Corresponding Author: Yusuf Muhammad-Bashir Owolabi, Department of Economics, Kulliyyah of Economics and Management Sciences, International Islamic University Malaysia, Malaysia 
injection of cash to the system to jump start the economy, both communities and organizations in the past have used complementary currencies and self help to bail themselves out of the financial quagmire. For instance, to douse the effect of the great depression, all around the world, "towns and associations of people of the most diverse types were seeking effective remedies to the crippling mood of the great depression, using tools like non-cash barter circles and self-created money" (Wuthrich, 2004). This self created money is known as complementary currency in the parlance of the economists. Notable complementary currencies of the past include, WIR in Switzerland, complementary currencies in US, Worgl in Austria, Curitiba in Brazil.

Another financial crisis has now prompted the world leaders to call for new monetary order. Nations, states, municipals, communities and associations have also started to look for permanent/temporary solutions (Gold dinar in Kelantan, Malaysia and Ache in Indonesia; barter trade in Perak). Since it is possible to have money without Exchange and market exchange without money as the case of barter and it is clear that exchange and trade preceded and created money rather than the other way around (Pamuk, 2000). People have renewed call for management techniques that reduce negative exposure to financial resources (Ionita et al., 2009). Business to business exchange barter exchange is a new type of business relation that is making wave among the company and other market actors (Melina, 2011).

However, barter is not a new system of transaction. The first system of exchange known to man is barter. But primitive barter gave way to money because of a number of problems in barter exchange. First is the problem of double coincidence of wants. In order for exchange to take place, individuals with marching requirements must be brought together. Second is the absence of common unit of measurement of value. For exchange to take place, the value of the items need to be known so as to know the ratio of exchange. Third is the divisibility problem. Many items cannot be subdivided without losing their value; as such many transactions cannot be done through barter. Fourth is the absence of common unit for which future payment agreement can be made. The fifth problem of barter is the lack of common unit to act as a store of value. (http://www.barternewsweekly.com/2010/05/21/ancient -barter-problems-modern-barter-solutions-2210/)

Using barter system for modern transaction therefore needs solutions to all these problems of primitive barter most especially when the world has become more complicated and the monetary system become more sophisticated. How is business to business barter exchange operates that has provided solution to the problems of primitive barter? What is the user's intent of using barter system? This research paper proposes to answer these questions by exploring the operation of and analyze the user's intention of business to business exchange in Malaysia in the context of the existing relevant theories.

Objectives of the study: The main objective of this study is to explore the operation of and analyze the user's acceptability of barter exchange in Malaysia. The specific objectives are:

- To explore the modus oprandi of barter trade in Malaysia

- To profile the demographic characteristics of the members of business to business barter exchange in Malaysia

- To analyze the factors associated with user's acceptance of barter trade in Malaysia

\section{Literature review:}

General overview of trade by barter: Barter is the exchange of goods, property, services. For other goods, without using money (Oxford Advanced Learner's Dictionary, 2010). Bartering according to Encyclopedia of Business is the exchange of goods and services among businesses. The traditional practice was between single businesses, however in recent years, bartering has been undertaken in an organized platform by a number of companies that belong to the same network (http://www.inc.com/encyclopedia/bartering.html).

Barter is regarded as the oldest form of exchange in the world (Oliver and Mpinganjira, 2011; Ionita et al., 2009), though an economy that work purely based on barter system has not been documented in history. Before the introduction of money, people exchange their goods or services for what they want from others (Ionita et al., 2009). But this form of commodity exchange faced many challenges. First there is a problem of double coincidence of wants. In order for exchange to take place, individuals with marching requirements must be brought together. This requirement makes barter system very cumbersome, even sometimes impossible, especially in an economy where specialization has taken place. There is always mismatch between wants of the potential exchangers. Second is the absence of common unit of measurement of value. For exchange to take place, the value of the items needed to be known so as to know the ratio of exchange. Third is the divisibility problem. Many items cannot be sub-divided without losing their value; as such many transactions cannot be done through barter. Fourth is the absence of common unit for which future payment agreement can be made. The fifth problem of barter is the lack of common unit to act as a store of value. Individual income can be consumed, invested or saved for future use. Barter economy does not provide way of storing the purchasing power of the saved 
income(http://www.barternewsweekly.com/2010/05/21/ ancient-barter-problems-modern-barter-solutions2210). Money economy does not have any of these problems, thus it supersedes barter (Ionita et al., 2009).

However, in the recent years, there has been increase in the growth rate of barter. The growth of barter has been linked to financial crisis occasioned by recession. The advent of modern barter can be traced to the introduction of business barter exchange system, Swiss Wirtschaftstring, or "WIR" (1934) in Switzerland during the great recession to help cope with the credit crunch after the stock market collapsed in 1929 (Stodder, 2009). It is a centralized system of multilateral exchange that uses no physical currency. Walrasian auctioneer showed that large scale moneyless clearing thrive when all necessary information can be centralized. Barter trade has changed greatly in the last two decades with the advent of Information Technology (IT) which makes centralized exchange feasible. This has solved the problem of coincidence of wants in the primitive barter exchange. Economists have even speculated computer-network exchange to supersede money exchange and centralized banking (Stodder, 2009).

Barter exchange has also evolved a tool for transaction inform of barter trade credit. This is the currency of trade in modern barter exchange and it normally commands the same value as the local currency. When transaction of goods or services take place, the selling business receives trade credit based on the local currency value of the product or service offered. The trade credit received is subsequently used by the business to buy goods and services it needed from other members that offered them. The evolution of trade credit in the modern barter transaction eliminates the problem of common measurement unit, facilitates future payment and serves as store of values (http://www.enotes.com/bartering-reference/bartering).

Apart from eliminating the constraint of traditional barter, there are many other benefits associated with modern barter. International Reciprocal Trade Association (IRTA, 2009) identified the common benefits to include increase in trade volume, facilitating entry into new markets, improved cash flow as well as relationship building. Barter trade helps business grow, attracting new customers who would not have patronized the company ordinarily for cash transaction and helps dispose inventory that is difficult to sell for cash (Oliver and Mpinganjira, 2011). Another benefit of barter trade is that it improves cash flow. The cash saved in inventory exchange can serve as a life line for other transaction(s) (SBA, 2008). The protracted negotiation in barter transaction can also facilitate long term relationship among business partners and build mutual trust (Ference, 2009).
However, there are also dark sides of modern barter exchange. Lithen (2002) noted that companies can enjoy the benefits of barter exchange only when they partake in it with caution. Protracted negotiation in barter, though have its advantage, can consume precious time of staff that could have been used for other business (Ference, 2009). If not properly managed, Satov (1996) observed that barter can have negative effect on company's cash flow. There are many things company needs money for which cannot be paid for by inventory such as employees salary and government tax; a disproportionally more business by barter than cash will have adverse effect on the company's ability to meet its cash obligations. Campbell (2009) and Vending (2003) raised the issue of quality and value of goods/services offer for sale through barter. Many companies trade in barter to offload excess inventory that is difficult to dispose through cash sale. There are also problems of disposing products offer for sale on barter platform, costumers becoming competitors and corruption/fraud and mismanagement of products offered for sale in barter transaction (Oliver and Mpinganjira, 2011). People have also accused business to business transaction of lack of public accountability and a means of evading tax (Melina, 2011).

\section{Review of some of the relevant theoretical frameworks: \\ Theory of Reason Action (TRA): This is a widely} studied social psychology theory. It is one of the most basic and influential theory of human behavior developed by Fishbein and Ajzen (1975) from earlier research such as Theory of Attitude by Heider in 1958. TRA has been used to predict a number of behaviors and defines relationships between beliefs, attitudes, norms, intentions and behavior. When TRA is used to explain use of adoption behavior, it has four general concept of an individual behavior of whether to use or reject an innovation, behavioral intention to perform the action, one's attitude towards performing the behavior and subjective norms influencing intention to perform the behavior which is a subject of their perception that people that matters to them think they should or should not perform the behaviour (Fishbein and Ajzen, 1975). TRA model depicts causal relationship among various variable in the model. It establishes that behavioral intention precedes actual behavior and it is a function of attitude towards behavior and subjective norms. Thus TRA can be summarized by the following equation Behavioral Intention $=\mathrm{f}$ (Attitude Towards Behavior, Subjective Norms).

Theory of Planned Behavior (TPB): The theory of planned Behavior was developed by Kuhl and Beckman (1985). It is an extension of theory of reasoned action 
which incorporates another determinant of intention, perceived behavioral control, into the TRA model. Perceived behavioral control is a function of skills, resources and opportunities to achieved outcome. Ajzen (1991) viewed it to be closely related to efficacy of belief concept. This concept has to do with belief of people and their capacity to produce effects (Masrom and Hussein, 2008). Kok et al. (1991) have shown that TPB has more explanatory ability compared to TRA in forecasting behavior. In his TPB framework, behavioral intention to precede actual behavior and behavioral intention is affected by either or all of attitude, subjective norms or perceived behavioral control. TPB is known to be one of the most important models employed to explain user's behavior (Kuhl and Beckman, 1985).

Social Exchange Theory (SET): Social exchange theory was borne out intersection among economics, psychology and sociology. The theory was developed by Homans (1958) to comprehend humans' social behaviour that underline their economic undertakings. The only basic difference between social exchange theory and economic exchange lies in the way the two viewed the actors. In economic exchange, the actors (person or firm) are viewed as interacting with the market (Emerson, 1962), responding to different market characteristics. On the other hand, social exchange theory sees the exchange relationship among actors as deeds that are premised on rewarding response from others (Blau, 1964). Cook (1977) observed that social exchange theory exists in different form, all of them driven by central concept of players exchanging resources through social exchange interaction. Cook and Emerson (1978) gave an illustration of how it works where social exchange relationship is a voluntary exchange of resources (x, y) between actors (A, B). Social behaviour is an exchange of material and non material goods in which actors try to get as much as what they give and the receivers are under pressure to reciprocate the equivalent of what they receive. For the actors in an exchange, what they give is their cost and what they get is the reward. What determines whether they stay in the relationship or opt out is the difference between the cost they incurred and the reward they obtained. If the difference is positive then they stay in the relationship, if it is negative they opt out of the relationship. The choice is them except there is no alternative, in such a case they are forced to endure the relationship (Homans, 1958).

Hypothesized model and hypothesis development: Based on the contextual and theoretical literature review above and leveraging on Plouffe (2007), this study hypothesized and empirically tested the following hypothesized model for acceptance of business to business barter transaction in Malaysia (Fig. 1).

Future behavioral intention: This refers to the individual intention to continue a particular behaviour into the future. This is similar to behavioural intention as proposed in TRA by Fishbein and Ajzen (1975), except that FBI studies barter transaction from the point of view that users intend to engage in barter transaction into the future. This is important as consumer's future behavioral intent of business to business transaction will determine its success. This shows the extent to which they are satisfied with the current behaviour, barter exchange, which affects their perceived sense of continuity. We specified FBI as endogenous factor in our study, thus there are no hypothesis from it to other constructs (Plouffe, 2007).

Satisfaction: Satisfaction is the pleasure individuals derive when they do something or get something that they wanted or needed to do or get. IRTA (2009) observed that millions of businesses throughout the world engage in barter exchange transactions. It may be assumed that businesses/people engage in barter transaction because of the satisfaction they derive from it. Shih and Vankatesh (2002) observe that current behaviour and usage tendencies concerning a mode of consumption should have positive relationship with the satisfaction derived from its consumption. For this reason, this study posits that:

H1: The more the satisfaction an individual derives from partaking in barter exchange, the more their future behavioral intent to continue with it.

Convenience: Convenience refers to how easy it is to use an innovation compare to the system it supersedes otherwise referred to as perceived ease of use. There are many supports in literature that a major driver promoting the exchange of goods is the ease and convenience with which the exchange can occur (McGarvey, 2002). Existing marketing literatures support the notion that if the consumers find the emerging mechanism easier than the previous one, they will embrace and adopt it (Wright et al., 2006). In the case of business to business barter exchange, desired good can be sourced and bartered among members on the internet at anytime, without the need for in-person retail visit, with one's goods (in form of trade credit), thereby saving the much needed cash and time for other transaction. Therefore, operationally this study defines convenience related to barter exchange as the degree to which a user values business to business barter exchange because it makes the consumption of goods among members simpler than sourcing it from the traditional market. Hence, it is proposed that: 


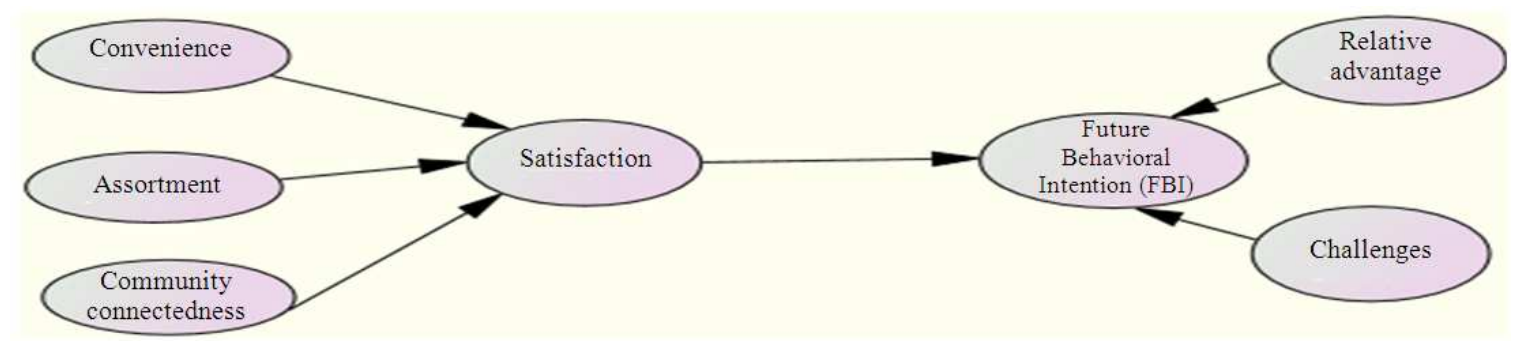

Fig. 1: Hypothesised model

H2: The more the member's sense that business to business barters exchange is convenient, the more is its positive impact on the satisfaction they derive from it.

Assortment: The advent of internet has added an almost endless variety of goods to almost all categories of individual consumption experience. Exploratory researches on barter trade have consistently indicated practitioner accounts of the presence of wide varieties of goods and services in online barter platform (Melina, 2011). This work therefore defines assortment construct as the extent to which an individual values barter exchanges because of the presence of a more robust depth and breadth of goods and services available for exchange within the desired platform for exchanges among members than is available through the orthodox market channels and means. Hence, this study posits that:

H3: The more the individual's sense that online barter trade provides a wide assortment of goods and services in their network, the more the positive effect on their satisfaction with barter exchange system.

Community connectedness: This is the degree to which a person perceives and values the broader sense of community and of being connected with others as a result of being a member of barter exchange platform. Studies have shown that consumers cherish the sense of connectedness to those who share similar interest with them when they exchange goods within one another (Plouffe, 2007). This evolving new community in human experience is what Prahalad (2004) termed "ecommunity" and it shares the same features with other forms of community examined in marketing literature (Wright et al., 2006). Barter exchange derives its strength from community connectedness as it is built around community currency based on trust, respect and mutual understanding of one another. It is based on law of reciprocity among members that exchange their resources like one community. Therefore, it is hypothesized that:
H4: The more the individual's sense that business to business barter exchange provides a sense of community and linking with others in the act of consuming goods and services in a desire platform, the more the positive effect on their satisfaction with barter exchange system.

Challenges: This is the degree to which an innovation is perceived as difficult to understand and use. Some innovations are readily understood by most members of a social system; others are more complicated and will be adopted more slowly. New ideas that are simpler to understand are adopted more rapidly than innovations that require the adopter to develop new skills and understandings (Rogers, 2003). As noted earlier, business to business barter transactions face many obstacles that may prevent/reduce its adoption. Anand (2007) noted that if the website of barter exchange network has friendly user interface and better navigation structure, it is easier for enterprise to use its search function and more possible to continue to use business to business barter exchange e-marketplace. Therefore, the hypothesis is put forward as follows:

H5: The greater the individual's perception that business to business barters transactions is riskier, the greater the negative effect on their future behavioral intention to continue to use it.

Relative advantage: Rogers (2003) defined relative advantage as the degree to which an innovation is perceived to be better than the one it supersedes. A number of researches have shown that the relative advantage of innovation has direct positive relation with its rate of adoption. The importance of online barter exchange platform is to provide information on the availability of goods and services available within the platform, allow the members to advertise their goods and services and facilitate the exchange of such goods and services among one another. As such, it serves several functions which include: matching buyers and sellers need, facilitation of transactions. The 
use of trade credit also eliminates the problem of common unit of measurement and trading with one's goods and services allow for saving of cash for other transactions. All these functions are added advantages to the users and the enterprises using it can make more profit and would like to continue to use it. Therefore, the hypothesis is put forward as follows:

H6: The relative advantage of Business to business barter exchange has direct relationship with its future behavioral intention.

\section{MATERIALS AND METHODS}

Research method and sources of data: This study employed mixed methods to achieve its objectives. The data for this study come from business to business to Business Barter exchange Malaysia (BBX). In line with its objectives, this work used two sets of data: qualitative data - in-depth interview, observation and document analysis- to uncover the operation of BBX Malaysia and a quantitative survey $(n=54)$, to answer the part on its acceptability. The in-depth interview was with the representative of BBX Malaysia, chosen by the company to attend to the questions after permission was sought and given to do so, having sent the question guide in advance. The interview was conducted within the company premises and the output was taped recorded for subsequent transcription and analysis. The analysis was sent to BBX to confirm it represents what was discussed. Observation was carried out by attending two of BBX quarterly barter fair to observe the events. The document analysis was carried out on the BBX documents, fliers and website. The participants for the survey were members/client that use BBX Malaysia platform. The survey was facilitated by the company for easy access to the members and out of 120 questionnaires sent, 54 were returned, all usable making effective response rate of $45 \%$.

Interview guide/measurement instrument: The interview questions employed in this study were structured around the work of Melina (2011). This contained open ended questions that asked about salient points regarding the operations of barter exchange transaction in Malaysia. The survey questionnaire used was adapted from Plouffe (2007), with some relevant questions on barter exchange from previous works (Rogers, 1995; 2003). The questionnaire contains two parts. In the first part, the respondents were asked to give their perception of business to business barter exchange to a series of question based on 5-point Likert scale. On the scale, "1" represent strongly disagree, "2" -disagree, "3" -neutral, "4" -agree and "5" -strongly disagree.

Instrument and scaling of measurement: To be sure that the indicators of each construct measured the same thing and for use in further analysis, each of the construct was subjected to exploratory Factor Analysis (EFA) and reliability test. The sample was found to be adequate and suitable for EFA as seen in their respective KMO and Bartlet's test. After removing poorly loaded indicators, each construct's indicators were found to load on a single factor. Out of 31 indicators originally used for the study from the survey questionnaire, 4 were removed to leave 27 indicators as the final one used for the study. The total variance extracted for each construct was above $60 \%$ minimum (Table 1 ).

Construct validity and reliability: The concept of validity and reliability is different between quantitative and qualitative research methods. In qualitative research, validity refers to credibility in research. This means that the description and or interpretation of human experience are done in a transparent manner such that people having the experience can immediately recognize it by the way the researcher describe them. Reliability on the other hand refers to dependability in qualitative research. This means that another researcher can clearly follow the decision trail adopted in the research and arrive at the same or comparable conclusion (AbdRahman et al., 2008). As noted earlier, consistency (credibility and dependability) in our qualitative data was achieved by sending the analysis to BBX for verification. The use of many data sources to triangulate our qualitative finding was also to this effect. In quantitative research however, reliability refers to the extent of consistency or accuracy to which an instrument measures its concept. In other words, reliability is the degree to which a measuring item gives similar result for repeated usages. Operationally, reliability is defined as the internal consistency of a scale which accesses the degree to which the items are homogeneous. Validity, on the other hand, shows the degree to which an instrument measures what it is designed to measure. If an instrument is not valid, then there is little use of the resulting data for the researcher (Rus-Eft, 1980). Instruments designed for a research should be examined for content validity to see whether the data collected measures an instrument it is supposed to measure. A scale that measures the conceived factor is valid and a scale that quantifies a concept always is reliable. The factor loading of each of the instruments on their factors is higher than 0.70 minimum, all with 
reliability's Crombach's alpha above 0.60 and communality above 0.05 . Table 2 presents the result of reliability and validity of the survey instrument.

Data analysis and hypotheses testing: The in-depth interview tape recorded was transcribed verbatim. The transcription was coded using our pre-mediated themes. This was supported by observation/field memo together with documentary evidences from various BBX sources. This was then presented inform of report of the operationalization of barter trade by BBX. Descriptive statistics was used to analyze the main characteristics of the sample data generated from the survey. Frequency distribution was used to present the demographic pattern of the respondents. The hypotheses of the study were examined through the use of Partial Least Square (PLS) technique. PLS is a member of second generation modeling techniques that has the ability to handle a large number of dependent and independent variables simultaneously. Like other Structural Equation Modeling techniques, a PLS model has both structural part and measurement part. However, PLS maximizes the variance of the dependent variables explained by the independent, unlike SEM that reproduces the empirical covariance matrix. PLS also contain weight relation component that is used to estimate case values of unobserved variables (Haenlein and Kaplan, 2004).

Henseller (2009) identified four reasons while PLS technique is now gaining popularity among researchers. First is that there are no distribution requirements for PLS and as such it can be used to analyze a non normal data. The second is that PLS path modeling can be used, when sample size is small, to evaluate the relationship among unobserved variables and their measurement items. The third advantage is the occurrence of modern day easy-to-use PLS software that has graphical interface which has made PLS modeling attractive. The fourth is the ability of PLS to handle improper or non convergent complex model when the number of latent and manifest variables is more compare to number of observations and "the number of indicators per latent variable is low" (Heywood cases).

Table 1: Average variance extracted

\begin{tabular}{|c|c|c|c|c|c|c|}
\hline \multirow{2}{*}{$\begin{array}{l}\text { Component } \\
\text { assortment }\end{array}$} & \multicolumn{3}{|c|}{ Initial eigenvalues } & \multicolumn{3}{|c|}{ Extraction sums of square loadings } \\
\hline & Total & Variance $(\%)$ & Cumulative (\%) & Total & Variance $(\%)$ & Cumulative \\
\hline 1 & 2.740 & 67.601 & 67.601 & 2.704 & 67.601 & 67.601 \\
\hline 2 & 0.591 & 14.774 & 82.375 & & & \\
\hline 3 & 0.430 & 10.794 & 93.124 & & & \\
\hline 4 & 0.275 & 6.876 & 100.000 & & & \\
\hline \multicolumn{7}{|c|}{ Community connectedness } \\
\hline 1 & 2.816 & 70.389 & 70.389 & 2.816 & 70.389 & 70.389 \\
\hline 2 & 0.591 & 14.781 & 85.171 & & & \\
\hline 3 & 0.403 & 10.087 & 95.257 & & & \\
\hline 4 & 0.190 & 4.743 & 100.000 & & & \\
\hline \multicolumn{7}{|l|}{ Satisfaction } \\
\hline 1 & 3.952 & 79.046 & 79.046 & 3.952 & 79.046 & 79.046 \\
\hline 2 & 0.359 & 7.172 & 86.217 & & & \\
\hline 3 & 0.336 & 6.711 & 92.928 & & & \\
\hline 4 & 0.239 & 4.776 & 97.704 & & & \\
\hline 5 & 0.115 & 2.296 & 100.000 & & & \\
\hline \multicolumn{7}{|c|}{ Future behavioral intention } \\
\hline 1 & 4.266 & 71.097 & 71.097 & 4.266 & 71.097 & 71.097 \\
\hline 2 & 0.654 & 10.906 & 82.003 & & & \\
\hline 3 & 0.515 & 8.588 & 90.591 & & & \\
\hline 4 & 0.251 & 4.190 & 94.780 & & & \\
\hline 5 & 0.170 & 2.833 & 97.613 & & & \\
\hline 6 & 143.000 & 2.387 & 100.000 & & & \\
\hline \multicolumn{7}{|c|}{ Relative advantage } \\
\hline 1 & 2.147 & 71.572 & 71.572 & 2.147 & 71.572 & 71.572 \\
\hline 2 & 0.570 & 18.995 & 90.567 & & & \\
\hline 3 & 0.283 & 9.433 & 100.000 & & & \\
\hline \multicolumn{7}{|c|}{ Convenience } \\
\hline 1 & 1.56 & 78.015 & 78.015 & 1.56 & 78.015 & 78.015 \\
\hline 2 & 0.44 & 21.985 & 100.00 & & & \\
\hline \multicolumn{7}{|l|}{ Complexity } \\
\hline 1 & 2.072 & 69.051 & 69.051 & 2.072 & 69.051 & 69.051 \\
\hline 2 & 0.584 & 19.481 & 88.531 & & & \\
\hline 3 & 0.344 & 11.469 & 100.00 & & & \\
\hline
\end{tabular}


End time Am. J. Applied Sci., 9 (9): 1422-1434, 2012

Table 2: Validity and reliability of the instruments

\begin{tabular}{|c|c|c|c|c|}
\hline Construct & Indicators & Factor loadings & Communality & Cronbach's alpha \\
\hline Future Behavioral Intention & Q25 & 0.792 & 0.627 & 0.918 \\
\hline KMO: 0.849 & Q26 & 0.776 & 0.602 & 0.881 \\
\hline Bartlett's Test: & Q27 & 0.840 & 0.706 & 0.860 \\
\hline \multirow[t]{5}{*}{$X^{2}(237.433 ; 15), 000$} & Q28 & 0.890 & 0.792 & 0.857 \\
\hline & Q29 & 0.857 & 0.734 & 0.819 \\
\hline & Q30 & 0.897 & 0.804 & 0.854 \\
\hline & & & & 0.840 \\
\hline & & & & 0.839 \\
\hline Assortment & Q9 & 0.769 & 0.591 & 0.823 \\
\hline KMO: .767 & Q10 & 0.802 & 0.643 & 0.778 \\
\hline Bartlett's Test: & Q11 & 0.845 & 0.713 & 0.761 \\
\hline \multirow[t]{2}{*}{$\mathrm{X}^{2}(84.698 ; 6), 000$} & Q12 & 0.870 & 0.756 & $\begin{array}{l}0.728 \\
0.931\end{array}$ \\
\hline & Q17 & 0.886 & 0.785 & $\begin{array}{l}0.931 \\
0.815\end{array}$ \\
\hline KMO: 0.839 & Q18 & 0.847 & 0.717 & 0.904 \\
\hline Bartlett's Test: & Q19 & 0.934 & 0.872 & 0.799 \\
\hline \multirow{3}{*}{$\mathrm{X}^{2}(219.179 ; 10), 000$} & Q20 & 0.905 & 0.820 & 0.850 \\
\hline & Q21 & 0.871 & 0.759 & 0.849 \\
\hline & & & & 0.858 \\
\hline Community Connectedness & Q13 & 0.843 & 0.710 & 0.771 \\
\hline KMO: 0.758 & Q14 & 0.908 & 0.824 & 0.693 \\
\hline Bartlett's Test: & Q15 & 0.866 & 0.751 & 0.761 \\
\hline \multirow[t]{2}{*}{$X^{2}(104.731 ; 6), 000$} & Q16 & 0.728 & 0.531 & 0.878 \\
\hline & & & & 0.705 \\
\hline Convenience & Q6 & 0.883 & 0.780 & 0.500 \\
\hline KMO: 0.500 & Q7 & 0.883 & 0.780 & 0.500 \\
\hline \multirow{2}{*}{\multicolumn{5}{|c|}{$\begin{array}{l}\text { Bartlett's Test: } \\
X^{2}(19.405 ; 1), 000\end{array}$}} \\
\hline & & & & \\
\hline Relative Advantage & Q31 & 0.847 & 0.697 & 0.669 \\
\hline KMO: 0.654 & Q32 & 0.908 & 0.825 & 0.597 \\
\hline Bartlett's Test: & Q8 & 0.802 & 0.643 & 0.697 \\
\hline $\mathrm{X}^{2}(54.266 ; 3), 000$ & & & & 0.760 \\
\hline Complexity & Q33 & 0.761 & 0.579 & 0.789 \\
\hline KMO: 0.671 & Q35 & 0.863 & 0.746 & 0.639 \\
\hline Bartlett's Test: & Q36 & 0.864 & 0.747 & 0.638 \\
\hline $\mathrm{X}^{2}(44.811 ; 3), 000$ & & & & \\
\hline
\end{tabular}

Sources: Author's computation

Unlike other structural equation modeling techniques such as LISREL, AMOS, EQS, Partial least square does not give the overall model fit indices such as CFI, RAMSEA, GFI; what is used to evaluate the model is the total number of significant paths in the structural model together with the percentage variance explained $\left(\mathrm{R}^{2}\right)$ in the key latent constructs to determine the nomological validity of the model. The minimum level of statistical significant normally reported in PLS is $\mathrm{p} \leq 0.05$ :

\section{RESULTS AND DISCUSSION}

\section{Report of Interview, Observation and document analysis:}

Brief history of BBX: Business-business exchange Malaysia $(\mathrm{BBX})$ is a part of $\mathrm{BBX}$ international that comprises of more than 15,000 business entities and operates in seven different countries of Australia, India, Singapore, Costa Rica, New Zealand, Taiwan and Malaysia. Though BBX international was founded in 1993, BBX Malaysia was founded in 2011. BBX Malaysia is the union of BBX international and Modern
Barter (M) Sdn Bhd to offer a cashless trading system to local small and medium businesses to trade in goods and services worldwide (http://biz.thestar.com.my/news/story.asp?file=/2011/3/ 19/business/8302965). The mission of BBX is to deliver a global cashless payment platform that is fairly equitable and highly profitable to all BBX members and at all times be community and socially responsible, using a currency known as BBX trade dollars. Some of the benefits of $\mathrm{BBX}$ to its member businesses are to increase sales, create cost savings and improve the general financial performance of their business by taking advantage of spare or under-utilized capacities that exist. BBX in Malaysia was prompted by the desire to create more business for the members outside the traditional cash transaction thereby increase their sales and customers in an effort to boost business opportunity that had been affected by the persistent credit crunch that followed the 2007 global financial crisis.

Organization: Business to business Malaysia is like any other typical small businesses managed by the 
owner with small number of staff. Its membership is drawn from business entities operating in Kuala Lumpur and its locality. This coverage was determined by the owners who wish to exploit the potential market within the capital city before extending its tentacle to other parts of the country. BBX on average has more than 100 members businesses; which normally make less than $30 \%$ of their sales through BBX platform. BBX operates like a private club and membership is granted to interested individual(s) by the owner after they have fulfilled the membership requirements. It gets these members through three major ways: the first is through company's advertisement/marketing. The second way is by the members who are satisfied with the services and opportunities they obtained from BBX. The third means is through the joint effort of the costumers and BBX who identify the business partners of their clients and invite them to also take the advantages provided by cashless transaction. Membership is of two types: personal membership or business membership. Potential member can join through the office or by apply online on the company's website

(http://www.ebbx.com/Home/Page.aspx?PageID = 2) to fill in the required information. This information is processed within seven days followed by BBX representative visit to the potential costumer to confirm their information. A potential client must have a viable registered business that must have been in operation for more than a year. The business is evaluated for credit worthiness and upon satisfying the company's requirements, BBX cards and approval information is delivered to the client. Depending on the volume of the costumer's business, BBX issue an instant credit line of at least 10,000 to as much as 100,000 trade credits to the costumer to participate in its business to business barter exchange.

BBX operates as a clearing house for its member. The system of trading is underpinned by the principle of barter. However, the actual products and services are bought and sold with their value recorded by BBX, using trade credit. Trade credit is the BBX barter currency that has the same value as the Malaysia ringgit. This monetary unit is referred to as credit because it is against the constitution to use trade ringgit in Malaysia. However, the value is still the same. BBX provides monthly statements, issues sales vouchers, maintains several methods of credit authorization for all transactions and issues interest free credit limits according to the trading capacity of the members. BBX has an online platform with which it coordinates and monitors the business activities of her members. This platform is provided by the parent company in Australia. On the company's website, each member has their own platform with which they can display their goods and services, search for what they need from the platform or receive information from the provider. Apart from these there are other avenues provided by the company for the members to meet in order to know one another and to interact. These include: monthly meeting at the head office, quarterly barter fair, end of the year get together.

Services to members: $B B X$ provides an attractive range of services to its members. BBX serves members:

- As a Marketer, BBX actively promotes a member's goods or services to a captive market formed by the network of other member's businesses. That is, the Exchange acts as a "promoter" through its publication of a master directory, new members, news flashes, newsletters, frequent trade events (dinners, functions, shows or auctions) and personal representations

- As a Broker, BBX actively seeks trading opportunities for all its members by sourcing goods or services which members require, internationally

- As a Record-Keeper, BBX functions like a computerized bank clearing house, providing monthly statements of members' trading activities.

- As a Consultant, BBX provides its members with the knowledge, procedures, tools and contacts necessary to conduct successful trading within BBX Network (BBX Members Information Booklet)

Public Accountability and Source of income: BBX is a registered company in Malaysia. As such, it is bound to abide by all the rules and regulations binding every business entity especially the one that relates to its modes of operations. It is accountable to the state as well as its members. BBX, just like other business entity pays tax to the government. Thus they serve as a platform to help the government to mobilize tax from the businesses that take place on their platform. This tax, charged as $6 \%$ value added tax on every transaction on BBX is remitted back to the government. To be able to do this, the company keeps accurate and up to date information on every transaction it facilitates. As noted earlier, BBX serves as the custodian of the members' transactions and payment among one another. Thus they provide monthly information to the members on their trading activities. This information includes monthly statements, issues sales vouchers, maintains several methods of credit authorization for all transactions. BBX obtains its own income from another $5-7 \%$ charged on every transaction it facilitates. 
Monitoring and control: Monitoring and control of BBX clients is facilitated by the use of information technology. The software application is provided by the parent company (BBX international) domicile in Australia. Business exchanges by members are centralized and all transaction is recorded and make available to the BBX as data in real time. With this monitoring tool available; BBX can manage her member's activities. Company representatives also pay visits to members from time to time to observe their activities and provide avenue to give valuable advice to the client on the best way to maximize the benefits afforded by barter trade. In BBX office every business owner is assigned a trade coordinator whose duty is to call them every two weeks to see how they can help them. If they need to buy or sell something they can source for members who want to dispose off what they need or those who want to buy their products. In BBX, exchanges are structured in such a way as to provide members with good and services which complement one another. This discourages unhealthy competition that leads to uneconomical discounting of members good and services within the system. The quality of products offer for sale on BBX platform is also guaranteed. Members are required to be trustworthy at all time and always make sure the quality of the products offer for sale are the same as those provided on their computerized trading account. Potential buyers can also inspect the products to be sure it satisfies the advertised conditions.

Sales and marketing: Melina (2011) identifies lack of trade activities which is due to lack demand for items offered in the exchange as a common problem in barter exchanges. This is a serious issue that requires concerted effort from the management. BBX devises a number of ways to effect sales on their platform. These include: advertisement, referral call from current business owner to new business owner, expertise advice on how to save cash through online barter trade, barter fair, auction. BBX also allows a transaction to be in cash and barter together, depending on the worth of the product.

Challenges and limitation: The main challenge that is limiting the activities of BBX borders on how to get more businesses to participate in barter exchange so as to increase members' opportunity of being able to get wide range of goods and services on the platform.

Users acceptability of barter exchange in Malaysia: This part presents the finding from the survey of BBX members on their perception on business to business barter exchange in Malaysia to determine their future behavioral intention about the usage of barter exchange. Majority (40\%) of BBX clients are aged between 31 and 40 years of age. This is followed by those above 50 years of age $(22.2 \%)$, while those aged between 20 and 30 year and 41 and 50 constitute $18.5 \%$ each. In terms of gender, majority of business to business barter exchange members are male, $61.1 \%$ while the remaining $38.9 \%$ are female. Looking at the monthly income distributions, more than $75 \%$ of the respondents earn monthly income above 5000 ringgits while the remaining less than $25 \%$ have a monthly income below 5000 ringgit.

Table 3: Result of the hypothesized structural links

\begin{tabular}{lllll}
\hline Hypothesis & Effect & Path coefficient & p-value less than & Remark \\
\hline H1 & Satis $\rightarrow$ FBI & 0.23 & 0.05 & Supported \\
H2 & Convi $\rightarrow$ Satis & 0.14 & 0.22 & Not supported \\
H3 & Assort $\rightarrow$ Satis & 0.37 & 0.01 & Supported \\
H4 & Comm $\rightarrow$ Satis & 0.47 & 0.01 & Supported \\
H5 & RelAdv $\rightarrow$ FBI & 0.55 & 0.01 & Supported \\
H6 & Chal $\rightarrow$ FBI & -0.21 & 0.08 & Not supported \\
\hline
\end{tabular}

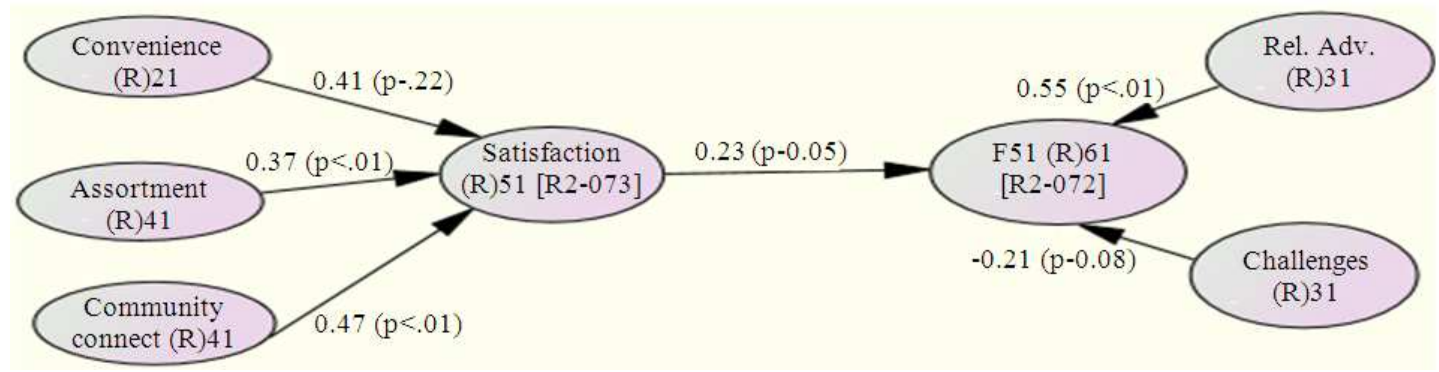

Fig. 2: PLS result of the hypothiesised structural model 
As per education level of the surveyed members, $85 \%$ of them have education above diploma level, $11 \%$ have only high school certificate and the remaining 3.7\% received other sources of education. Looking at the sources of awareness of members to barter exchange in Malaysia, the overwhelming $74 \%$ got their awareness from BBX agents, $22 \%$ through their business partners and just $3.7 \%$ know barter exchange through the internet. The volume of trade through barter has received wide attention in literature since barter is viewed as market for excess inventory. About $80 \%$ of BBX members reported less than $30 \%$ transaction on the platform, which corroborates around $15 \%$ normally reported in literature, while only $20 \%$ claimed they transact more than $30 \%$ in barter exchange. This also validates the $\mathrm{BBX}$ representative claim in the interview that members transact about $20 \%$ of their business through the platform.

As per business/occupation of BBX members, it was discovered that there are as many businesses as the number of respondents with all different forms of businesses ranging from accounting service, through media up to nongovernmental organization. This also confirms the company's policy of having varieties of business to prevent unhealthy competitions among members. In terms of experience of members in barter (number of months already in business to business barter exchange), $75 \%$ of the members surveyed reported having less than 12 months membership while the remaining $25 \%$ claimed they have been involved in barter transaction for more than 12 months. This indicates the aggressiveness of BBX Malaysia after it begins its operation after the alliance.

Hypothesis testing: The result of the hypothesized structural links of the research model in this study using PLS (WarpPLS software) analysis together with their associated p-value is presented in Table 3 and Fig. 2.

The result shows that all the hypothesized structural links exhibit the expected signs with four out of the six path coefficients statistically significant. This is an indication that the hypothesized relationships in the model are supported by the data. Five of the paths (Satisfaction to FBI; and Community connectedness, Assortment and Convenience to satisfaction) showed positive signs while the last one (Complexity to FBI) showed negative sign. Future behavioral intention is jointly predicted by Satisfaction $(\beta=0.23, \mathrm{p}<0.05)$ and Relative Advantage $(\beta=0.55, \mathrm{p}<0.01)$. Satisfaction is jointly predicted by Community connectedness $(\beta=$ $0.47, \mathrm{p}<0.01)$ and Assortment $(\beta=0.37, \mathrm{p}<0.01)$. Though the path between Complexity to FBI exhibited a moderate degree of significance of $p<0.1$, but as noted earlier, significance level of $\mathrm{p} \leq 0.05$ is normally consider in PLS analysis (Plouffe, 2007).

Explaining future behavioral intention: The future Behavioral Intention of business to business barter trade members in Malaysia is jointly predicted by Satisfaction $(\beta=0.23, p<0.05)$ and Relative Advantage $(\beta=0.55, \mathrm{p}<0.01)$. These two constructs jointly explained $72 \%$ of variance on FBI $\left(\mathrm{R}^{2}=0.72\right)$. This is an indication of a very good explanatory power of the model of FBI. In comparing this finding with previous results, the study support Plouffe (2007) that found a significant relationship between satisfaction and FBI. However, the explanatory power of the current research model is higher than that obtained by Plouffe (2007) with $\mathrm{R}^{2}=37.5 \%$. This perhaps may be as a result of inclusion of other constructs (Relative Advantage and Complexity) to our model and underscores the importance of Relative Advantage of barter exchange to its adopters.

Explaining satisfaction: Satisfaction of members with business to business barter exchange in Malaysia is jointly explained by Community connectedness $(\beta=$ $0.47, \mathrm{p}<0.01)$ and Assortment $(\beta=0.37, \mathrm{p}<0.01)$. These two constructs jointly explained $73 \%$ of the variance on user's Satisfaction with business to business barter transaction in Malaysia $\left(R^{2}=0.73\right)$. This is also an indication of good explanatory power of the construct, satisfaction. The finding also presents a higher variance explained than obtained by Plouffe (2007). Also, while convenience and community connectedness predicted satisfaction in Plouffe (2007), in the present study, it is assortment and community connectedness that predicted satisfaction. This also shows the importance of community connectedness and that availability of wide varieties of goods and services enhance satisfaction in barter trade which in turn impact positively on its future behavioral intention.

\section{CONCLUSION}

This research work studied the operationalization and acceptability of business to business barter trade in Malaysia using mixed methodology. Two sets of data were obtained from BBX Malaysia (qualitative and quantitative). The qualitative data was by in-depth interview, observation and document analysis on BBX mode of operation in Malaysia. This aspect covers the origin, organization, public accountability and challenges of barter trade in Malaysia in order to cover the study's objective number one. The quantitative aspect was a survey member's perception of business to business barter trade in Malaysia. The survey questions 
covered aspects of members' satisfaction, convenience, assortment, community connectedness, relative advantage and complexity to determine their future behavioral intention, using structural equation modeling method of analysis with PLS technique.

The first objective of this study was achieved using qualitative methods of in-depth interview, document analysis together with observation to triangulate the findings. BBX was established in Malaysia at the beginning of 2011. It draws its members from Kuala Lumpur and its environment, with more than one hundred business entities. These members covering a wide range of business activities to provide assortment and prevents unhealthy competitions among members. Her currency is trade credit that commands the same value as ringgit Malaysia. Its mode of operation is through providing each of the members a platform on its website where they can advertise and also shop for goods and services among members. BBX serves as clearing house to her members and provide a range of services. It is also accountable to both members and public and pay tax based on value added tax collected on the transaction carried out on its platform. It gets its income through service charges charged to the members for the services it rendered to them. BBX's main challenge is few number of members on its platform.

The second objective of profiling the socioeconomic characteristics of members was achieved through descriptive statistics of the surveyed data. Most of the members fall between the age group 31-40 years $(40 \%)$. BBX members are highly educative. More than $85 \%$ of the respondents have education above diploma level. The members' main source of awareness to BBX is through the company's agent. Most of them report less than $30 \%$ trade through barter $(80 \%)$; and there are as many businesses as the number of respondent surveyed on the platform.

The third objective of determining the user's acceptability of business to business barter transaction in Malaysia was achieved through subjecting the survey data to SEM analysis using PLS. The result shows that all the hypothesized structural links exhibit the expected signs with four out of the six path coefficient statistically significant. The future Behavioral Intention of business to business barter trade members in Malaysia is jointly predicted by Satisfaction and Relative Advantage. Satisfaction of members with business to business barter exchange in Malaysia is jointly explained by Community connectedness and Assortment. The paths between convenience to satisfaction and complexity to future behavioral intention are not statistically significant.
Although this study shows a lot of impressive findings, caution should however be taking in generalizing its result based on the following grounds. The first is that this is an exploratory study, much work still need to be done to refine the instruments and confirm the finding. The second limitation has to do with small number of sample size. It should also be noted that this is not a confirmatory study and thus should not be interpreted as such. Finally, business to business barter exchange was still new when the study was conducted; hence a follow up study is required to ascertain the consistency of the members on the finding of the study.

\section{REFERENCES}

AbdRahman, N.S., H. Suhailah and M. Badzis, 2008. A Practical Guide to Interview in Educational Research. 1st Edn., CTL/IIUM Printing, Selangor.

Ajzen, I., 1991. The theory of planned behavior. Org. Behav. Hum. Decis. Process., 50: 179-211.

Anand, A., 2007. E-satisfaction--a comprehensive framework. Proceedings of the 2nd International Conference on Internet and Web Applications and Services, May 13-19, IEEE Xplore Press, Morne, pp: 55-55. DOI: 10.1109/ICIW.2007.30

Blau, P.M., 1964. Exchange and Power in Social Life. 3rd Edn., Transaction Publishers, New Brunswick USA., ISBN-10: 0887386288, pp: 352.

Campbell, D.G., 2009. Corporate trade or barter: Financial flexibility for today's economy. Am. Assoc. Advert Agencies Bull., 7008: 1-16.

Cook, K.S and R.M. Emerson, 1978. Power, equity and commitment in exchange networks. Am. Soc. Rev., 43: 721-739. DOI: $10.2307 / 2094546$

Cook, K.S., 1977. Exchange and power in networks of interorganizational relations. Soc. Q., 18: 62-82.

Emerson, R., 1962. Power-dependence relations. Am. Sociol. Rev., 27: 31-41.

Ference, M., 2009. Fight economic woes by trading your way to new business. Promotional Product Assoc. Mag.

Fishbein, M. and I. Ajzen, 1975. Belief, Attitude, Intention, and Behavior: An Introduction to Theory and Research. 1st Edn., Addison-Wesley Pub. Co., Reading, Mass, ISBN-10: 0201020890, pp: 578.

Haenlein, M. and A.M. Kaplan, 2004. A beginner's guide to partial least squares analysis. Understand. Stat., 3: 283-297.

Henseller, J., 2009. On the convergence of the partial least squares path modeling algorithm. Comput. Stat., 25: 107-120. DOI: 10.1007/s00180-0090164-x 
Homans, G.C., 1958. Social behavior as exchange. Am. J. Sociol., 63: 597-606. DOI: 10.1086/222355

Ionita, F., S. Burlacu and A. Gaidargi, 2009. Modern approaches to management of alternative trade systems. Rev. Int. Comparative Manage.

IRTA, 2009. Modern trade and barter. International Reciprocal Trade Association.

Kok, G., A. DeVries, N. Muddle and V.J. Strecher, 1991. Planned health education and the role of selfefficacy: Dutch research. Health Educ. Res., 6: 231-238. DOI: 10.1093/her/6.2.231

Kuhl, J. and J. Beckman, 1985. Action Control, from Cognition to Behavior. 1st Edn., Springer-Verlag, Berlin, New York, ISBN-10: 038713445X, pp: 286.

Lithen, R., 2002. Pragmatic ideas for considering barter. Brandweek, 20: 40-43.

Masrom, M. and R. Hussein, 2008. User Acceptance of Information Technology: Understanding Theories and Models. 1st Edn., Venton Publishing, Malaysia ISBN: 967506546X, pp: 207.

McGarvey, R., 2002. Long Live P2P. EContent, 25: 1825.

Melina, Y., 2011. Business-to-business barter exchange: A viable market place.

Oliver, P. and M. Mpinganjira, 2011. Barter trading: An empirical investigation of management practices. Afr. J. Bus. Manage., 5: 12256-12263. DOI: 10.5897/AJBM11.273

Pamuk, S., 2000. A Monetary History of the Ottoman Empire. 1st Edn., Cambridge University Press, Cambridge, ISBN-10: 0521441978, pp: 276.

Plouffe, C.R., 2007. Examining "Peer-to-Peer" (P2P) systems as Consumer-to-Consumer (C2C) exchange. Eur. J. Market., 42: 1179-1202. DOI: $10.1108 / 03090560810903637$
Prahalad, C.K., 2004. The co-creation of value, (invited commentaries on 'evolving to a new dominant logic for marketing'). J. Market., 68: 18-27.

Rogers, E.M., 1995. Diffusion of Innovations. 4th Edn., Simon and Schuster, ISBN-10: 0029266718, pp: 519.

Rogers, E.M., 2003. Diffusion of Innovations. 5th Edn.. Simon and Schuster, ISBN-10: 0743258231, pp: 576.

Rus-Eft, D.F., 1980. Validity and reliability in survey research technical report no 15). Am. Inst. Res Behav. Sci., 143.

Satov, S., 1996. Fair exchange. CA Mag.

SBA, 2008. The ancient act of bartering goes mainstream.

Shih, C.F. and A. Vankatesh, 2002. Beyond adoption: Development and application of Use Diffusion (UD) model to study household use of computers. J. Market., 68: 59-72.

Stodder, J., 2009. Complementary credit networks and macroeconomic stability: Switzerland's Wirtschaftsring. Applied J. Econ. Behav. Organ., 72: 79-95. DOI: 10.1016/j.jebo.2009.06.002

Vending, R.E., 2003. Creating value through cash saving. Fin. Exec. Int., 19: 59-59.

Wright, L.T., A. Newman and C. Dennis, 2006. Enhancing consumer empowerment. Eur. J. Market., 40: 925-935. DOI: $10.1108 / 03090560610680934$

Wuthrich, W., 2004. Alternatives to globalization: Cooperative principle and complementary currency. 